\title{
The Development of Entrepreneurial Mindset Measurement Instruments as Predictor for Wetland's MSMEs Business Sustainability
}

\author{
Hastin Umi Anisah ${ }^{1}$, Wimby Wandary ${ }^{2)}$ Meiske Claudia ${ }^{3)}$ \\ ${ }^{1)}$ UNLAM, Banjarmasin, Indonesia* \\ E-mail: humianisah@unlam.ac.id \\ ${ }^{2)}$ UNLAM, Banjarmasin, Indonesia \\ E-mail: wimbywandary@unlam.ac.id \\ 3) UNLAM, Banjarmasin, Indonesia \\ E-mail: $\underline{\text { meiske.claudia@gmail.com }}$
}

Research Aim. This study aims to provide an academic justification on promoted Entrepreneurial Mindset aspects by Kasali, thus it will provide the eligible contribution within entrepreneurial research field. In this research, we employ it to determine the wetland's MSMEs business sustainability.

Research Design. This research designed in quantitative approaches, empowering Likert scale - resulted in ordinal data from the distributed questionnaire as the primary source data for a test of validity and reliability testing. PLS will be employed as the data analysis tools, as it is used to predict its contribution toward MSMEs business sustainability.

Expected Result. The expected result of this study is to obtain some valid and reliable aspects of Entrepreneurial Mindset by Kasali that can be practically used in entrepreneurship study generally, especially in MSMEs.

Keywords: entrepreneurial mindset, Kasali, MSMEs, wetland.

\section{Introduction}

In general, the entrepreneurial study focused on small and medium enterprises/ SMEs. However, recently it branches out by including the lower level enterprises within, the micro enterprises - MSMEs. Afterwards, the study for those enterprises appears to not yet accommodate the micro enterprises business agenda/ activities which carried on by the poor and marginal community - that labor market unable to reserve. Their entrepreneurial activities are their pole for family support - the business activities to survive. Under such situation, the general indicators for sustainable business, such as revenue and employee growth then become not suitable to be employed as micro business sustainability measurement. The fact on the field shows that their product for trading activities was very limited in variety and quantity in years. There were no signs of the increased capital but they were able to continue their business within traditional commerce within years. They were 'barefoot entrepreneurs' (Wilson \& Weston, 2012). Under such condition, assumed that there were living entrepreneurial values or characters but has not yet gained the academic justification which led the general opinion that as a profession, being an entrepreneur is never been an option. They are forced to be one - since they had no choice to support their life or family. However, their microeconomic activities were last long in business. These take place at the local traditional market located in Handil Bhakti district at Pasar Semangat Dalam. There were barefoot entrepreneurs that carried out their trading activities along the riverside roads - since the area was the wetlands. The trading activity and products were conventional and simple. They trade local products, such as vegetables, fruits, river fish, rice, general groceries etc. They have come a long way to get to the market every day. Instead of using 
land transportation mode, some of them must take dozens of kilometers down the river by jukung (the traditional boat of Banjarese in Borneo) - for 1 (one) to 3 (three) hours of sailing from home. The enormous effort they have made for the result that seemed unbalanced, arouse the curiosity of 1) how to measure the wetland's MSMEs entrepreneurial mindset; 2) how are their EM and BS?, and 3) is EM significantly influence BS for wetland's barefoot entrepreneurs? This research seeks to provide an understanding of the fundamental aspects of the entrepreneurial mindset and the unlimited opportunities that it can provide for wetland's MSMEs. So, the comprehension will enrich the creation, implementation and evaluates/review the entrepreneurial decision, especially for this specific object.

\section{Literature Review}

Wilson and Weston (2012) describe barefoot entrepreneur[ing] as the entrepreneurial practice by the poor and marginal - as the research object, which usually missed in the entrepreneurial study when taking the micro, small, and medium enterprises for the sample. Then, it was simply defined that barefoot entrepreneurs are entrepreneurs who come from marginal and poor communities. The determination to try - put aside economic deficiency to stop their micro business.

\section{Entrepreneurial Mindset}

Entrepreneurship is a perspective that changes the way people think in a revolutionary way, about decision making and how to run a business - beyond the academic disciplines and concepts of traditional business creation and small business management. Entrepreneurship is the mindset; as a frame of thought and action that can empower a person to succeed. The need for entrepreneurial thinkers within society appears as the response to the rapid and complex world changes. The entrepreneurial mindset exposes opportunities, triggers ambition, and encourages innovation that shifts every day thinking into a new framework, empowers people to identify problems, apply solutions, and make connections using creative, critical, communicative, and collaborative thinking. Consequently, the entrepreneurial mindset is able to empower the layman to achieve remarkable achievements. There is no right formula that guarantees the success of an entrepreneur, but there is a common thread that enables one to succeed in entrepreneurship, the mindset - as a guide to the employer's decision to act. According to The Ice House Entrepreneurship Program, entrepreneurship mindset as the basis of beliefs and assumptions encourages behaviors that enable entrepreneurs to succeed. Everyone is likely to benefit if they are able to understand and apply the entrepreneurial mindset to any situation that demands change in life. Entrepreneurial mindset (EM) is a dynamic process of vision, change, and creation (Kuratko et al., 2016). It can be concluded that entrepreneurial mindset (EM) is about how to encourage people to do what seems impossible.

The mindset is the whole / unity of the beliefs, the shared values, the criteria, the expectations, the attitudes, the habits, the decisions, and the opinions expressed in regard to self, others, or life - more as a filter built to interpret everything seen and experience (Kasali et al., 2010). Thus, the mindset moves behavior. There are 7 basic entrepreneurs who are introduced as the basic character of the entrepreneurial mindset, termed as the habitual entrepreneurs (McGrath \& MacMillan, 2000), they are: 1) Action-oriented. Do not delay and act immediately even it in uncertain situations. Under the principle of seeing and do, the risk exists to be confronted and conquered by action and expertise; 2) Simple thinking - Simplify the complexity by seeing the problem clearly and solving the problems one by one - stages per stage; 3) Passionately seek new opportunities - Always look for new opportunities. Sometimes, new opportunities can be found from a completely new venture, or from the same 
endeavor. In an entirely new venture - entrepreneurs are always willing to learn new things, form networks, and add to their landscape or business scope. In the same venture, will diligently seek new alternatives, so that profits are gained not only from new businesses and products but also from new ways; 4) Pursue opportunities with enormous discipline Pursuing opportunities with high discipline - not only alert to opportunities but also ensure that opportunities are followed up. Opportunities are not only sought, but also created, opened, and clarified. While entrepreneurs invest and bear the risks, entrepreneurs must be disciplined because for the sake of opportunities, they fighting time. They invest only when the competition arena is attractive and opportunities mature; 5) Pursue only the very best opportunities - just take the best chance. Entrepreneurs are much disciplined in limiting the number of businesses/projects done because they avoid wasting energy to pursue every opportunity that exists; 6) focus on execution - Focuses on implementation, especially adaptive ones - the adaptive execution. Immediately implement - not analyze the idea to fail. Adaptive - related to its ability to change direction toward real opportunities, and how best to use them to grow or easily adjust to facts /problems in the field; and 7) engage the energies of everyone in their domain - focusing the energy of everyone in their respective fields, because entrepreneurs do not work alone. Entrepreneurs use the hands and minds of others, internally and externally and build networks, lead, unite, motivate and communicate to achieve opportunities. Entrepreneurs create and maintain relationships within the network.

\section{Business Sustainability and MSMEs}

Initially, sustainability is defined as the capacity/endurance to maintain an entity, outcome, or process over time. In the article: A Framework for Business Sustainability, it is stated that business sustainability is a means to achieving an organization's vision and mission (Pojasek, 2007), that as a means of achieving the company's vision and mission, a formidable effort is the application of knowledge, skills, equipment, and techniques to provide the availability of context for the organization's activities, products, and services; identify the critical objectives and targets (rooted in the vision and mission of the organization) to be achieved; removes obstacles or disturbances that may hinder the achievement of organizational targets and objectives; understands the organizational control level to deal with mitigation impacts and strategies when facing obstacles or disruptions; and can continue to achieve its critical objectives and targets; creating criteria and/or triggers for implementing response to crises and emergency conditions, follow-up responses, and response recovery procedures'; ensure that staff and managers understand overall accountability and responsibility in accordance with their portions in the event of an emergency or stakeholder problem, and ensure that the understanding persists; builds consensus and commitment to business sustainability, requirements and business integrity as part of the way business operates.

MSMEs have their own characteristics, not just "little big businesses" (Darcy et al., 2014), which characteristic affects the way business operates and operates. Resource-based view highlights the relationship between internal HR and talent-related capabilities as a potential source of competitive advantage - not just based on the perspective of a large company.

\section{Methodology}

First, to measure entrepreneurial mindset (EM) among barefoot entrepreneur, we intend to build research instrument - a questionnaire. The building of the entrepreneurial mindset instrument was made derived from Kasali et.al (2007) about the basic character for entrepreneurial mindset - which McGrath \& MacMillan (2000) acknowledges it as habitual entrepreneurs. They are: 1) action-oriented; 2) simple thinking; 3) passionately seek new opportunities; 4) pursue opportunities with enormous discipline; 5) pursue only the very best 
opportunities; 6) focus on execution, and 7) engage the energies of everyone in their domain. Meanwhile, for the business sustainability instrument, it was adapted from Pojasek (2007) who explain that a sustainable business is the application of business-related knowledge, skill, equipment, and techniques - especially in related to the MSMEs. Each indicator was sought for its particular meaning regards to the research object, the wetland's MSMEs barefoot entrepreneurs. In general, each indicator has been broke-down into 3 statement items which represent the meaning/purpose of each indicator it represents. Secondly, To describe each research variable, they are EM dan BS, we employed descriptive statistics to explain the gathered primary data conditions. It will explain how is it going under respondent's perception. And the last, to find out EM role to BS, we analyzed data using SmartPLS to specify the relationship among those two research variable.

\section{Sampling}

The non-probability sampling method by convenient sampling technique resulted in 27 local traders located at Pasar Semangat Dalam in Handil Bhakti district as research respondent. There were who are willing to participate in responding the research activities by voluntarily filling research questionnaire. Some of them tended to illiterate, so they were being accompanied to fill the research questionnaire. The resulted primary data then analyzed to provide an answer to the research question.

Our respondents consist of both genders, composed by $67 \%$ female and $33 \%$ of male respondent. Based on our previous research on Banjar culture (Anisah et al., 2015), we acknowledge that Banjarese kinship system tends to be bilinear system which impacts on the equal position for women/wife within family, which economically provide them the same right as the opposite gender to provide for their family - not just rely on their spouse or husband supports.

\section{Data analysis and Result}

Intended to build research instrument, we first excluded the outliers for both variables. Each variable was tested independently. By the level of significant used in 5\% or on a curve area of 0.475 , then Z-score value will lie between -1.96 to +1.96 . We employ the SPSS 21 for windows program for data analysis, as well as the descriptive statistics to spot outliers. The normally distributed data then considered as eligible for the next test of validity and reliability.

\section{Entrepreneurial Mindset (EM)}

For Entrepreneurial Mindset/EM, among 27 respondents, they were 8 outliers excluded for further data analysis. They were 19 respondents left who provide the normally distributed data. The next step was the test of validity and reliability for the research item. The statistical hypothesis for $\mathrm{H}_{0}$ is that the item score positively correlated to the factor score, and vice versa to the $\mathrm{H}_{1}$. The next step is determined the r-table values for the level of significance 5\% by $\mathrm{df}=\mathrm{n}$ cases $-2=19-2=17$ is 0.3077 . Among 7 indicators for EM, the 3rd data running resulted in valid and reliable items, which the r-count (Corrected Item-Total Correlation) was larger than the r-table of 0.3077 and the Cronbach's Alpha $(\alpha)$ is 0.731 which slightly larger than 0.70 .

\section{Table 1. Reliability Statistics}

\begin{tabular}{|r|r|}
\hline Cronbach's Alpha & N of Items \\
\hline, 731 & 6 \\
\hline
\end{tabular}

Table 2. Item-Total Statistics

\begin{tabular}{|c|r|r|r|r|r|c|}
\hline Code & $\begin{array}{c}\text { Scale Mean if } \\
\text { Item Deleted }\end{array}$ & $\begin{array}{c}\text { Scale Variance if } \\
\text { Item Deleted }\end{array}$ & $\begin{array}{c}\text { Corrected Item-Total } \\
\text { Correlation }\end{array}$ & $\begin{array}{c}\text { Cronbach's Alpha if } \\
\text { Item Deleted }\end{array}$ & $\begin{array}{c}\text { R-table for df }= \\
17 \text { is } 0.3077\end{array}$ & Validity \\
\hline ST4 & 17,37 & 16,912 &, 791 &, 691 & $>$ & Valid \\
\hline
\end{tabular}




\begin{tabular}{|c|c|c|c|c|c|c|}
\hline $\begin{array}{l}\text { ST6 } \\
\text { PS7 } \\
\text { PB013 } \\
\text { PBO15 } \\
\text { FE17 }\end{array}$ & $\begin{array}{l}18,26 \\
19,26 \\
17,21 \\
17,32 \\
18,47\end{array}$ & $\begin{array}{r}13,205 \\
9,427 \\
18,175 \\
17,895 \\
11,374\end{array}$ & $\begin{array}{l}, 589 \\
, 742 \\
, 329 \\
, 448 \\
, 486\end{array}$ & $\begin{array}{l}, 655 \\
, 593 \\
, 735 \\
, 724 \\
, 716\end{array}$ & $\begin{array}{l}> \\
> \\
> \\
> \\
>\end{array}$ & $\begin{array}{l}\text { Valid } \\
\text { Valid } \\
\text { Valid } \\
\text { Valid } \\
\text { Valid }\end{array}$ \\
\hline
\end{tabular}

The final test of validity and reliability for the original 16 items of EM questionnaire results in 6 valid and reliable items. The items left were items for 4 indicators to measure EM, they are: simple thinking, passionately seek new opportunities, pursue only the very best opportunities, and focus on execution.

Table 3. EM Description Statistics

\begin{tabular}{|c|c|c|c|c|c|c|c|}
\hline & & \multicolumn{2}{|c|}{ Simple Thinking } & \multirow{2}{*}{$\begin{array}{c}\text { Passionately seek } \\
\text { new opportunities } \\
\text { PS7 }\end{array}$} & \multicolumn{2}{|c|}{$\begin{array}{c}\text { Pursue only the very best } \\
\text { opportunities }\end{array}$} & \multirow{2}{*}{$\begin{array}{c}\begin{array}{c}\text { Focus on } \\
\text { execution }\end{array} \\
\text { FE17 }\end{array}$} \\
\hline & & ST4 & ST6 & & PBO13 & PBO15 & \\
\hline \multirow{2}{*}{$\mathrm{N}$} & Valid & 18 & 18 & 18 & 18 & 18 & 18 \\
\hline & Missing & & 0 & 0 & 0 & 0 & 0 \\
\hline Mean & & 4,17 & 3,28 & 2,22 & 4,33 & 4,28 & 3,06 \\
\hline Median & & 4,00 & 4,00 & 1,50 & 4,00 & 4,00 & 4,00 \\
\hline Mode & & & 2 & 1 & 4 & 4 & $1^{a}$ \\
\hline Std. Deviation & & ,383 & 1,227 & 1,665 & ,485 & ,461 & 1,731 \\
\hline Minimum & & & 2 & 0 & 4 & 4 & 1 \\
\hline \multirow[t]{3}{*}{ Maximum } & & 5 & 5 & 5 & 5 & 5 & 5 \\
\hline & 10 & 4,00 & 2,00 & ,90 & 4,00 & 4,00 & 1,00 \\
\hline & 25 & 4,00 & 2,00 & 1,00 & 4,00 & 4,00 & 1,00 \\
\hline \multirow[t]{3}{*}{ Percentiles } & 50 & 4,00 & 4,00 & 1,50 & 4,00 & 4,00 & 4,00 \\
\hline & 75 & 4,00 & 4,00 & 4,00 & 5,00 & 5,00 & 4,25 \\
\hline & 90 & 5,00 & 5,00 & 5,00 & 5,00 & 5,00 & 5,00 \\
\hline
\end{tabular}

a. Multiple modes exist. The smallest value is shown

From above table, we can see that there are 18 valid data processed readily. The ST (Simple Thinking) indicator's first item (ST4) mean score at 4,17 tells that in general, respondents perceive that there is/are always solutions for every problem. Their respond represents their positive attitude toward entrepreneurial problems they must confront with - they are struggling and persistently carry on their entrepreneurial activities even it confronts with barriers. The median score generated is 4 implies that $50 \%$ of the respondent agree with the item's statement within mostly respondent by the mode score generated in 4 .

For the next item, ST6 mean score of 3,28 reveals the doubt whether they will do the easiest things first. The median score generated is 4 implies that $50 \%$ of the respondent tends to agree with the item's statement within mostly respondent by the mode score generated in 3 (tend to agree with - meaning: in doubt feeling). Assume is they must dealing with choices within limitation as barefoot entrepreneurs - problems in the economy or financial/fund or place, they tend to consider the most important subject which delivered security in the. They tend to do something even they are in doubt about it, with a lot hope that it will return in good. Doing the easy one first is such a temptation to settle things or we can say that they tend to be pragmatic.

The next indicator's item, Passionately seeks new opportunities, at (PS7) - generated mean score at 2,22 represents our respondents that they are not passionately seeking new opportunities. In this case, they are selling their goods as the way it is - not seeking opportunities to increase the value of the product they sell by turning it into the culinary product, for example. The median score generated is 1,50 implies that $50 \%$ or the respondent disagree with the item's statement within mostly respondent by the mode score generated in 1. Yet, they are only selling goods not produce it. 
The next indicator's item, Pursue only the very best opportunities, at (PBO13) - generated mean score at 4,33 represents the most of the respondents feeling sure or confident that they occupy the best site for they stall. The median score generated is 4 implies that $50 \%$ of the respondent agree with the item's statement within mostly respondent by the mode score generated in 4 as well. Previously, as a pathway, the street market they were occupying at this moment was desolate - surrounding by wetland area. Before they were relocated there by the local government officers, they peddle at a front yard of the nearby mosque by the main road of Handil Bhakti. Some of them - who refuse to be relocated - choose to peddle somewhere place they assume to be better than at Semangat Dalam pathway. But today, the pathway becomes the main path for many cluster area and asphalt paved, a lot better than before it was. Their confident feeling leads to the willingness to be relocated gets the favorable answer.

The next item (PBO15) means to score at 4,28 express their choice of product for sale that they are only providing good that people really need in daily life - such as vegetables, fruits, local spices, herbs, etc. as well as the 9 staples. The median score generated is 4 implies that $50 \%$ of the respondent agree with the item's statement within mostly respondent by the mode score generated in 4 as well. They perceived that the best chance to sell out their product is by providing their consumer with the daily processed product for family consumption - does not matter if there are many of other within the same market selling the similar product since they could only provide in a small amount of it. Based on this indicator, these barefoot entrepreneurs pursue their best opportunity they have.

The next item (FE17) of Focus on execution indicator, generated means score of 3,06 express that they tend to procrastinating things they should do. The median score generated is 4 implies that $50 \%$ or the respondent disagree with the item's statement within mostly respondent by the mode score generated in 1 . They are not focused on execution, they seem always to have the best moment for everything which provides them well in the future. It seems related to their conception of Banjar local culture, bubuhan, operated in this case as fellow solidary among barefoot entrepreneurs that they will do something as long as it is beneficial for them as a group - not individually. The biggest possibility that they accept this statement is within the context of time literally.

\section{Business Sustainability (BS)}

For Business Sustainability, among 27 respondents, they were 9 outliers excluded for further data analysis. They were 21 respondents left who provide the normally distributed data. The statistical hypothesis for $\mathrm{H}_{0}$ is that the item score positively correlated to the factor score, and vice versa to the $\mathrm{H}_{1}$. The next step is determined the r-table values for the level of significance $5 \%$ by df $=\mathrm{n}$ cases $-2=21-2=19$ is 0.2914 . Among 3 indicators for BS, the 2nd data running resulted in valid and reliable items, which the r-count (Corrected Item-Total Correlation) was larger than the r-table of 0.2914 and the Cronbach's Alpha ( $\alpha$ ) is larger than 0.901.

\section{Table 4. Reliability Statistics}

\begin{tabular}{|r|r|}
\hline Cronbach's Alpha & N of ltems \\
\hline, 901 & 8 \\
\hline
\end{tabular}

Table 5. Item-Total Statistics

\begin{tabular}{|c|c|c|c|c|c|c|}
\hline Code & $\begin{array}{l}\text { Scale Mean if } \\
\text { Item Deleted }\end{array}$ & $\begin{array}{l}\text { Scale Variance if } \\
\text { Item Deleted }\end{array}$ & $\begin{array}{l}\text { Corrected Item- } \\
\text { Total Correlation }\end{array}$ & $\begin{array}{l}\text { Cronbach's Alpha } \\
\text { if Item Deleted }\end{array}$ & $\begin{array}{c}\text { R-table for df }=19 \\
\text { is } 0.2914\end{array}$ & Validity \\
\hline $\begin{array}{l}\text { P19 } \\
\text { P20 } \\
\text { P21 } \\
\text { K22 } \\
\text { K23 }\end{array}$ & $\begin{array}{l}30,43 \\
30,62 \\
30,10 \\
30,14 \\
30,67\end{array}$ & $\begin{array}{r}12,957 \\
11,348 \\
14,490 \\
14,329 \\
15,633\end{array}$ & $\begin{array}{r}, 739 \\
, 690 \\
, 820 \\
, 866 \\
, 525\end{array}$ & $\begin{array}{r}, 884 \\
, 910 \\
, 882 \\
, 879 \\
, 902\end{array}$ & $\begin{array}{l}> \\
> \\
> \\
> \\
>\end{array}$ & $\begin{array}{l}\text { Valid } \\
\text { Valid } \\
\text { Valid } \\
\text { Valid } \\
\text { Valid }\end{array}$ \\
\hline
\end{tabular}




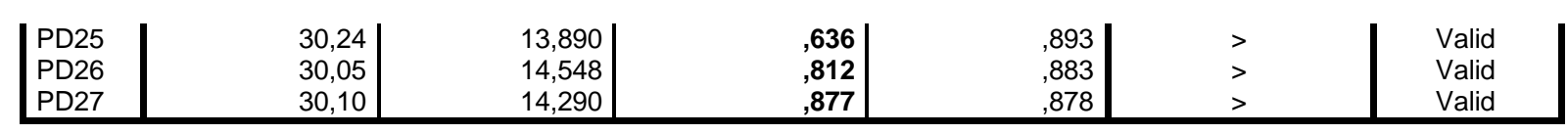

The final test of validity and reliability for the original 9 items of BS questionnaire results in 8 valid and reliable items. The items left were items for 3 indicators, they are Knowledge of trading, trading skills, and trading equipment.

Table 6. BS Description Statistics

\begin{tabular}{|ll|r|r|r|r|r|r|r|r|}
\hline & & P19 & P20 & P21 & K22 & K23 & PD25 & PD26 & PD27 \\
\hline N & Valid & 18 & 18 & 18 & 18 & 18 & 18 & 18 & 18 \\
Mean & Missing & 0 & 0 & 0 & 0 & 0 & 0 & 0 & 0 \\
Median & & 4,22 & 3,94 & 4,56 & 4,50 & 3,94 & 4,39 & 4,56 & 4,56 \\
Mode & 4,00 & 4,00 & 5,00 & 4,50 & 4,00 & 4,50 & 5,00 & 5,00 \\
Std. Deviation & 5 & 5 & 5 & 4 & 4 & 5 & 5 & 5 \\
Minimum & & 808 & 1,211 &, 511 &, 514 &, 539 &, 778 &, 511 &, 511 \\
Maximum & 3 & 2 & 4 & 4 & 3 & 2 & 4 & 4 \\
& 10 & 5 & 5 & 5 & 5 & 5 & 5 & 5 & 5 \\
& 25 & 3,00 & 2,00 & 4,00 & 4,00 & 3,00 & 3,80 & 4,00 & 4,00 \\
\multicolumn{1}{|c|}{ Percentiles } & 50 & 4,00 & 4,75 & 4,00 & 4,00 & 4,00 & 4,00 & 4,00 & 4,00 \\
& 75 & 5,00 & 5,00 & 5,00 & 4,50 & 4,00 & 4,50 & 5,00 & 5,00 \\
& 90 & 5,00 & 5,00 & 5,00 & 5,00 & 5,00 & 5,00 & 5,00 & 5,00 \\
& & &
\end{tabular}

a. Multiple modes exist. The smallest value is shown

From above table, we can see that there are 18 valid data processed readily. The first item of Business Sustainability (P19) mean score generated is 4,22 express that respondents mostly agree with the statement that they can calculate their generated profit from their trading activities even in a very simple manner - the subtraction between their expenses and revenue. The median score generated is 4 implies that $50 \%$ of the respondent agree with the item's statement within mostly respondent by the mode score generated in 4 as well.

The next item (P20) mean score generated is 3,94 which there is a very strong tendency to agree with the state instead of feeling doubt, express that know by experience that people consume a certain product daily to serve food for the family. By this knowledge, they can assure that they can sell their product for daily consumption. They use their simple market knowledge to choose their product to sell - so they only sell products that people need. The median and mode are 4 which tells us that $50 \%$ or respondent agree the statement of they sell only goods that people need and in the majority, most of them choose 4 (agree) because it will represent them. The next $(\mathrm{P} 21)$ resulted in the mean score of 4,56 expressing the respondent agrees that they are profit oriented. The median score of 5 tells that $50 \%$ of the respondent fully agree with the statement, with mostly choose 5 (fully agree with) in the item. They make their living by their entrepreneurial activities at Pasar Semangat Dalam. The next K22 is representing an indicator of trading skills. Generated mean for this item is 4,50 expressing the respondent agrees that they can prepare they stall well for trading activities. The median score of 4,5 tells that $50 \%$ of the respondent fully agree with the statement, with mostly choose (mode of) 4 (which mean they fully agree with) the statement. Preparing stall is easy for them since they are getting used to it. Some of them may spread a plaited mat as a patch for their goods - then simply fold it after it is done to go home. The next indicator (K23) mean score of 4 expressing the respondent agrees that they are able to tide their stall up quickly. The median score result at 4,5 tells that $50 \%$ of them fully agree with this statement and support by the generated mode at 5 that most of them are fully agree with. Considering the practical mat they are using and the semi-permanent stall they employ, tide up activities is such an ease. So, we can conclude that they have enough trading skill as they need it to trade in pasar Semangat Dalam. The next indicator is Trading Equipment (PD), measured in PD26 
and PD27. The item of the PD26 result in the mean score of 4,56 as well as PD27, tells that they serve consumer to ease them into such things, in the example: (plastic) bag; knife to cut the goods when consumer buy them, using a cutting board, dan appropriate wrap. They have a sufficient trading equipment they need to serve well.

\section{The Role of Entrepreneurial Mindset toward Business Sustainability}

the last research question leads to test a hypothesis which state that EM is significantly influenced BS for wetland's barefoot entrepreneurs. The data analysis result by using the relevant statistical software, provide us with the model below.

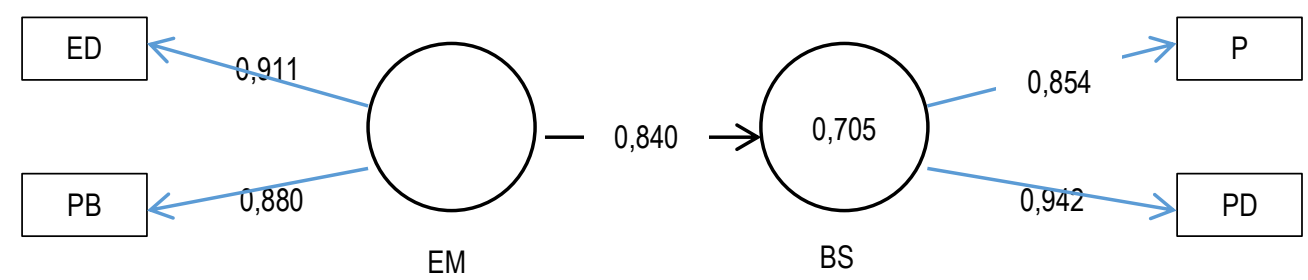

Part 1. The path coefficient from the latent EM to BS is 0,840 which means that entrepreneurial mindset/EM strongly influence BS. EM contribution to ED/ pursue opportunities with enormous discipline in 0,911 and tp $\mathrm{PB} / \mathrm{Pursue}$ only the very best opportunities in 0,880 . Meanwhile, BS/business sustainability contribution to P/knowledge in 0,854 and to PD/equipment in 0,942 shows that BS strongly influence knowledge and equipment. Resulted R-square of 0,781 means that EM with its 2 indicators influences BS with its indicator as well. And only $21,9 \%$ influenced by other factors outside this research model.

Part 2. The fit model at Average Variance Extracted (AVE) for BS is 0,565 means that the model's fit for BS is better than EM which is 0,339. It seems that only BS at this moment wich able to explain each its indicator - that EM is not yet able to explain its indicator. The composite reliability $\left(\rho_{\mathrm{A}}\right)$ for BS is 0,806 dan $\mathrm{EM}(0,670)$ which is more than 0,6 (according to Hair et al) tells that the internal consistency for both of variables is above standard value. The alpha score for EM is 0,618 and BS are 0,218 are below the minimum alpha score requirement which means that both of variant not yet reliable.

\section{Finding and Discussion}

The first research problem promoted is about the existence of the measurement tools of EM for wetland's MSMEs. Data analysis resulted in the generation of the 6 valid and reliable measurement items/statement of EM for wetland's MSMEs (from total 16 items), as we provide it in Table 5.

Table 7. Entrepreneurial Mindset Items

\begin{tabular}{|c|c|c|}
\hline Item & Indicators & Item Statements \\
\hline ST4 & \multirow{2}{*}{ Simple thinking } & 1. I believe that there will be solutions for every problem \\
\hline ST6 & & 2. I will do the easiest thing to do first \\
\hline PS7 & $\begin{array}{l}\text { Passionately seek } \\
\text { new opportunities }\end{array}$ & 3. I am selling my goods as it is as well as after I re-processed it \\
\hline \multirow{2}{*}{$\begin{array}{l}\text { PBO13 } \\
\text { PBO15 } \\
\end{array}$} & \multirow{2}{*}{$\begin{array}{l}\text { Pursue only the very } \\
\text { best opportunities }\end{array}$} & 4. I am sure that I choose the best location for my stall \\
\hline & & 5. I only trade goods that people need \\
\hline FE17 & Focus on execution & $\begin{array}{l}\text { 6. I am not a person who used to procrastinating the thing I have } \\
\text { to do }\end{array}$ \\
\hline
\end{tabular}


Meanwhile, for MSMEs business sustainability it resulted in 8 valid and reliable measurement items/statement of BS for wetland's MSMEs, as we provide it in Table 6.

\section{Table 8. Business Sustainability Items}

\begin{tabular}{|c|c|c|}
\hline Item & Indicators & Item Statements \\
\hline P19 & \multirow{3}{*}{$\begin{array}{l}\text { Knowledge of } \\
\text { trading }\end{array}$} & 1. I can calculate my generated profit \\
\hline P20 & & 2. I only provide goods that people need \\
\hline P21 & & 3. My trading activities is profit oriented \\
\hline K22 & \multirow{2}{*}{ Trading skills } & 4. I am preparing my stall well \\
\hline K23 & & 5. I am able to tide up my stall quickly \\
\hline PD25 & \multirow{3}{*}{ Trading equipment } & 6. I have enough space to display my goods \\
\hline PD26 & & 7. I provide my consumers with (plastic) bag whenever they need it \\
\hline PD27 & & 8. I have eligible equipment to serve my consumer \\
\hline
\end{tabular}

As research instrument, which tends to quantitatively approach, we are aware of the shortcoming related to the data condition for analysis - which then-cases or the amount of eligible data is less than 30, they are 27 in total then lessen to be 17 cases for EM and 19 cases for BS as normal distributed primary data. Unlike the BS instrument, we were losing 3 EM indicators (they are: Action Oriented; Pursue opportunities with enormous discipline, and Engage the energies of everyone in their domain) among 7 indicators for analysis. But, we are also aware that at a certain level, these provide us with relevant information of our respondents, the barefoot entrepreneurs.

We describe the Entrepreneurial Mindset among barefoot entrepreneurs that they tend to be the 'push entrepreneur' since they tend to be pragmatic, did not passionately seek new opportunities, pursue the only best opportunity (as they understand), and did not really focus on execution. They were pushed to do their entrepreneurial activities because they have to, rather than seek for actualization. For the Business sustainability, at their situation, they have relevant knowledge just to survive the business - not the highly profitable one, the skilled enough and equipped well as barefoot entrepreneurs. And the last, we have not yet able to answer the 3rd research question as well as to test the hypothesis to find out whether EM is significantly influenced BS for wetland's barefoot entrepreneurs since the data was not yet reliable within the analysis. This finding is relevant to the previous test for an instrument that at this research is better to consider as pre-test of EM instrument.

\section{Conclusion/Implication}

Within individual perception to measure EM for wetland's MSMEs; we found that not all of Kasali's indicators of entrepreneurial mindset are valid and reliable. There are only 4 eligible indicators as we can see in Table 5. Under the data circumstances, we conclude that the instrument for EM measurement generated by this study is eligible for a preliminary study to further development of EM instrument for measurement. The general problem for instrument validity is considered ambiguity that leads its respondent to uncertain meaning. In this case, the most potential constraint is language that respondents tend to be only proficient with the local language - the Banjar language. So, there was also the potential that they did not truly comprehend the meaning of the sentences even we already did our best to explain what does it mean, and the fact that many of them were not graduated from elementary school embedded with a very thick local language. Since the data analysis has not yet provided us 
with the reliable instrument to measure EM, it becomes an open chance to pursue it in the future research.

\section{References}

Anisah, H.U., January, W. \& Widyarfendhi, 2015. The Role of Banjar Culture in Improving Organizational Performance through the Development of Business Unit Center towards SelfReliance Civil Society Organization in The Municipality of Banjarmasin - South Kalimantan. AFBE Journal, Vol.8(No.1), pp.67-77.

Bryant, A. \& Bryant, J.E., 1998. Wetlands and Entrepreneurs: Mapping the Fuzzy Zone between Ecosystem Preservation and Entrepreneurial Opportunity. Journal of Organizational Change Management, Vol. 11(Iss. 6), pp.112-34.

Darcy, C., Hill, J., McCabe, T. \& McGovern, P., 2014. A Consideration of Organisational Sustainability in the SME Context: A Resource-based View and Composite Model. European Journal of Training and Development, Vol.38(No.5), pp.398-414.

Fisher, R., Maritz, A. \& Lobo, A., 2014. Evaluating Entrepreneurs' Perception of Success: Perception of Success. International Journal of Entrepreneurial Behaviour \& Research, Vol. 20(No. 5), pp.478-92.

Ghozali, I., 2013. Aplikasi Analisis Multivariete dengan Program IBM SPSS 23. Semarang: Badan Penerbit Univeristas Diponegoro.

Goyit, G. \& Bako, W.S., 2012. The Sustainability of Small and Medium Scale Enterprises in Jos Metropolis, Nigeria. International Journal of Advanced Studies in Business Strategies and Management, 4(3), pp.58-77.

Hassan, S.H., 2014. The role of Islamic Values on Green Purchase Intention. Journal of Islamic Marketing, Vol. 5(No. 3), pp.379-95.

Kasali, R. et al., 2010. Modul Kewirausahaan untuk Program Strata 1. Jakarta Selatan: Penerbit Hikmah.

Kuckertz, A., Berger, E.S.C. \& Mpeqa, A., 2015. The More the Merrier? Economic Freedom and Entrepreneurial Activity. Journal of Business Research, pp.pp.1-6.

Kuratko, F., O'Connor, A. \& Frederick, H., 2016. Entrepreneurship:

Theory/Process/Practice. 4th ed. South Melbourne: Cengage Leaming Australia Pty Limited.

Loucks, S., Martens, M.L. \& Cho, C.H., 2010. Engaging Small- and Medium-sized Businesses in Sustainability. Sustainability Accounting, Management and Policy Journal, 1(2), pp.178-200.

McGrath, R.G. \& MacMillan, I., 2000. The Entrepreneurial Mindset: Strategies for Continuously Creating Opportunity in an Age of Uncertainty. Boston: Harvard Business School Press. 
Moorthy, M.K. et al., 2012. A Study on Factors Affecting the Performance of SMEs in Malaysia. International Journal of Academic Research in Business and Social Sciences, 2(4), pp.pp.224-239. Available at: www.hrmars.com/journal.

Petrini, M. \& Pozzebon, M., 2010. Integrating Sustainability into Business Practices: Learning from Brazilian Firms. Brazilian Administration Review, 7(4), pp.362-78. Available at: http://www.anpad.org.br/bar.

Pojasek, R.B., 2007. A Framework for Business Sustainability. Environmental Quality Management, pp. 81-88.

Purwaningsih, R. \& Kusuma, P.D., 2015. Analisis Faktor-Faktor yang Mempengaruhi Kinerja Usaha Kecil dan Menengah (UKM) dengan Metode Structural Equation Modelling (Studi Kasus UKM Berbasis Industri Kreatif Kota Semarang). In rosiding SNST ke-6 Tahun 2015. Semarang, 2015. Fakultas Teknik Universitas Wahid Hasyim - Semarang.

Robbins, S.P. \& Judge, A., 2013. Organizational Behavior. 15th ed. New Jersey: Prentice Hall.

Sarwono, J. \& Narimawati, U., 2015. Membuat Skripsi, Tesis, dan Disertasi: Partial Least Square (PLS-SEM). I ed. Yogyakarta: CV ANDI Offset.

Schermerhorn, Jr, J.R., Hunt, J.G., Osborn, R.N. \& Uhl-Bien, 2010. Organizational Behavior. 11th ed. Hoboken: John Wiley \& Sons, Inc.

Subagyo, P.E.A., Savio, D.S. \& Arsyianti, L.D., 2014. Pengaruh Karakter Wirausahawan terhadap Keberhasilan UMKM: Perspektif Islam. Iqtishodia: Jurnal Ekonomi Islam Republika, 22 Mei. p.23.

Wagner III, J.A. \& Hollenbeck, J.R., 2010. Organizational Behavior: Securing Competitive Advantage. New York: Routledge.

Wilson, N. \& Weston, A., 2012. Barefoot Entrepreneurs. Organization, 19, pp.563-85. 